\title{
Efficiency Improvement of Three-Phase Cascaded H-Bridge Multilevel Inverters for Photovoltaic Systems
}

\author{
Nuntawat Thitichaiworakorn, Nattapon Chayopitak, and Natchpong Hatti \\ National Electronics and Computer Technology Center (NECTEC), Pathumthani 12120, Thailand \\ Correspondence should be addressed to Nuntawat Thitichaiworakorn; nuntawat.thitichaiworakorn@nectec.or.th
}

Received 1 March 2016; Accepted 15 May 2016

Academic Editor: Santolo Meo

Copyright (C) 2016 Nuntawat Thitichaiworakorn et al. This is an open access article distributed under the Creative Commons Attribution License, which permits unrestricted use, distribution, and reproduction in any medium, provided the original work is properly cited.

\begin{abstract}
Medium-scale photovoltaic (PV) systems using cascaded H-bridge multilevel inverters have a capability to perform individual maximum power point tracking (MPPT) for each PV panel or each small group of panels, resulting in minimization of both power losses from panel mismatch and effect of partial shading. They also provide high power quality, modularity, and possibility of eliminating $\mathrm{dc}$ - $\mathrm{dc}$ boost stage and line-frequency transformer. However, each PV panel in the system is subjected to a double-linefrequency voltage ripple at the dc-link which reduces the MPPT efficiency. This paper proposes a dc-link voltage ripple reduction by third-harmonic zero-sequence voltage injection for improving the MPPT efficiency. Moreover, a control method to achieve individual MPPT control of each inverter cell is also presented. The validity and effectiveness of the proposed methods were verified by computer simulation.
\end{abstract}

\section{Introduction}

Renewable energy technology has undergone a substantial development in the last three decades. Photovoltaic (PV) system is promising and one of the fastest growing renewable energy sources. The worldwide cumulative installed capacity of PV systems has been increasing exponentially in the last decade and recently has reached a level of $178 \mathrm{GW}$ at the end of 2014 [1] due to the decreasing price per PV panel and government policies in many countries.

Generally, the PV system topologies can be categorized into four groups: (1) central inverter, (2) module-integrated inverter, (3) string inverter, and (4) multistring inverter [2-5]. In the central inverter topology, several PV strings (PV panels connected in series) are connected in parallel with one blocking diode per string to form a single dc-link and are connected to the grid via a central inverter. This topology has a simple structure, a reliable control, and a low initial cost. However, with only one centralized maximum power point tracking (MPPT) control, the energy yield can be easily reduced by the effects of panel mismatch and partial shading. Dividing PV panels into smaller groups with individual MPPT control can mitigate the problem $[6,7]$. The module-integrated inverter topology is another side of the spectrum. In this topology, one converter operates with only one or a few PV panels. Thus, the power loss from panel mismatch can be minimized and the effect of partial shading can be mitigated. However, the voltage amplification by either dc-dc boost stage or transformer is required. The module-integrated inverter topology is intended for small PV systems lower than $500 \mathrm{~W}$. For the string inverter topology, one PV string is connected to the grid via one inverter. Therefore, the benefit of this topology is a trade-off between central inverter and module-integrated inverter topologies. Finally, the multistring inverter topology combines higher energy yield of the string inverter with low initial cost of the central inverter topology. Several PV strings, each with one dedicated $\mathrm{dc}-\mathrm{dc}$ converter, are connected to a central inverter. Moreover, in addition to the traditional two-level inverters, the use of neutral-point-clamped (NPC) inverter for either central inverter, string inverter, or multistring inverter topologies has also been reported $[8,9]$.

Recently, cascaded H-bridge multilevel inverter topology has gained interest from many researchers for PV system 


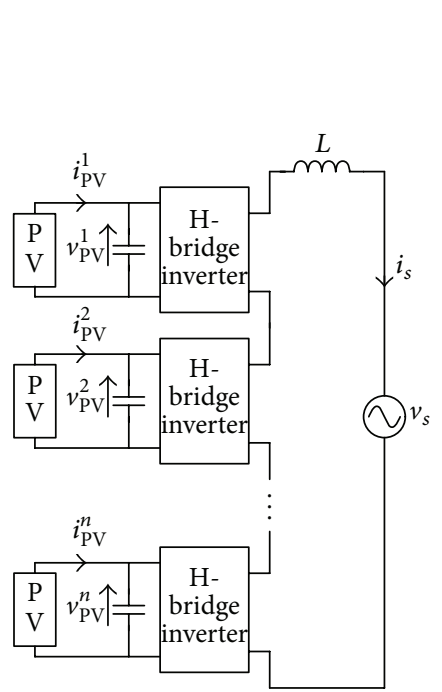

(a)

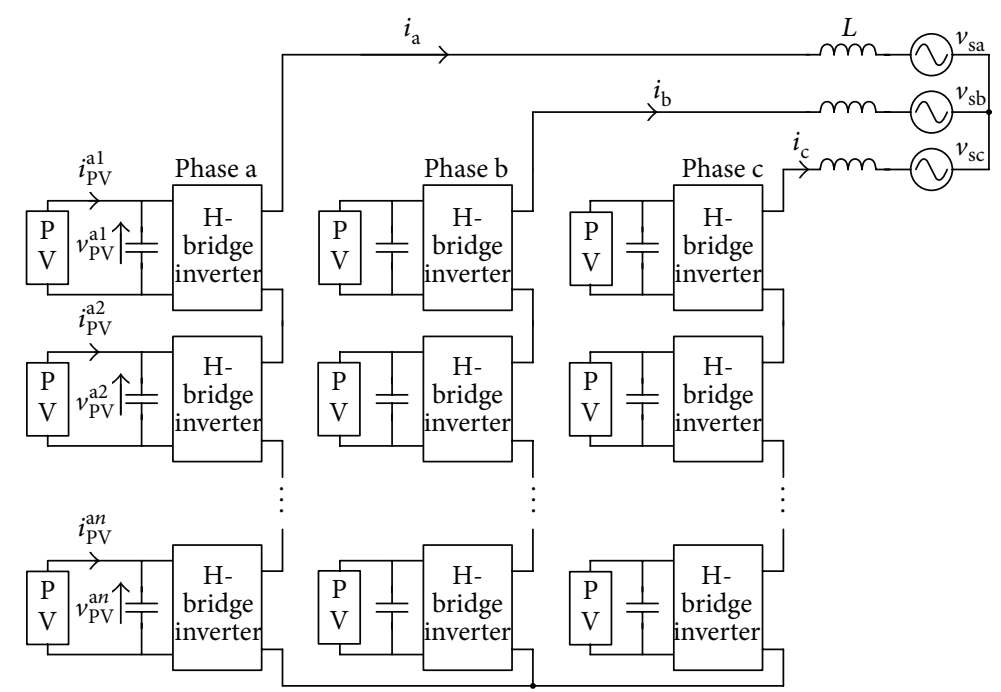

(b)

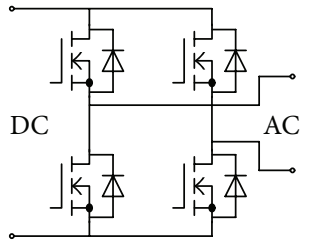

(c)

Figure 1: Topology of the grid-connected cascaded H-bridge PV system. (a) Single-phase system. (b) Three-phase system. (c) H-bridge inverter.

applications [10-20]. It is characterized by a cascade connection of several H-bridge inverters per one phase. The system topology is depicted in Figure 1 which can be either a single-phase system in Figure 1(a) or a three-phase system in Figure 1(b), depending on the system power rating. A single PV panel can be directly connected to the dc side of each $\mathrm{H}$ bridge inverter to implement the concept of one converter per one PV panel. This is similar to that of the moduleintegrated inverter topology. In this case, it is possible to achieve the distributed MPPT control by each H-bridge inverter individually $[10,11]$ that greatly optimizes the energy yield from the PV panels. The advantages of this system can be summarized as follows:

(i) The MPPT can be performed individually for each PV panel to eliminate the effects of panel mismatch and partial shading, thus maximizing the energy production in contrast to the system utilizing the centralized MPPT.

(ii) Due to the voltage scalability of the cascaded multilevel converter, it is possible to eliminate the $\mathrm{dc}-\mathrm{dc}$ boost converter stage and line-frequency transformer for voltage elevation. This can reduce the weight and cost of the PV system.

(iii) The cascaded multilevel converter produces multilevel PWM output voltage waveform which has low voltage THD (Total Harmonic Distortion) and low current THD. Therefore, EMI emission and harmonic filter are minimized.

(iv) Due to multiplicative effect of switching frequency, the system can achieve high output switching frequency while the device switching frequency is low. Thus, the switching power loss is low.

(v) The modularity of the system enables the reduction of manufacturing cost and easy maintenance operation.

On the other hand, the system can be extended to a largecapacity PV system in which the dc-link of each H-bridge inverter can be connected to several PV strings with one dedicated dc-dc converter per string that is similar to the concept of multistring inverter topology $[12,13]$. This kind of system can achieve a power rating of a few megawatts with the voltage rating in the medium-voltage level. However, this paper focuses on a smaller PV system with one PV panel per one H-bridge inverter for simplifying the analysis to be presented in this paper.

Since each PV panel is directly connected to a singlephase dc-ac inverter, it is subjected to power fluctuation of an angular frequency of $2 \omega$ produced by the ac side of the $\mathrm{H}$ bridge inverter. The power fluctuation causes voltage ripple at the terminal of the PV panel connected to the dc-link capacitor. The low-frequency ripple of the dc-link voltage is significant in this topology because each cell is a singlephase inverter. This is unlike in a three-phase inverter such as NPC or conventional two-level inverter where the three phase 


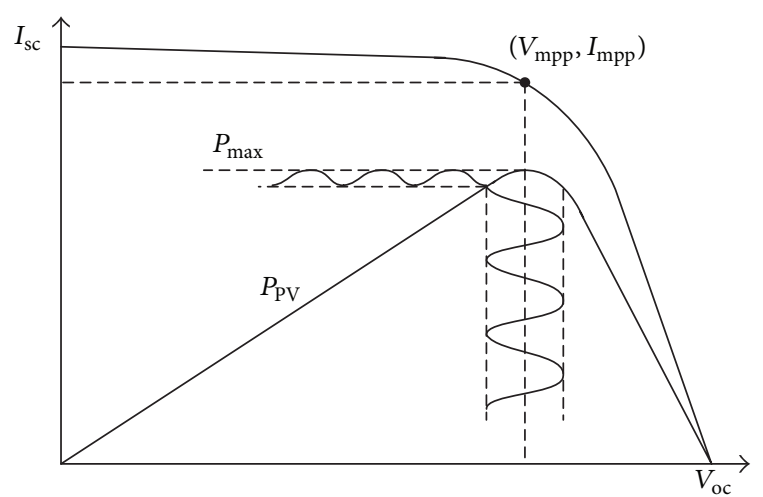

FIGURE 2: Effect of dc-link voltage ripple on the MPPT [3].

legs share a common dc-link in which the ripple frequency is higher $(3 \omega)$ but much smaller in amplitude. The voltage ripple causes an output power ripple from the PV panel because the terminal voltage swings around the voltage at MPP. This power ripple makes the average output power somewhat lower than the power at MPP, thus reducing the MPPT efficiency, as described in Figure 2 [3]. Since the MPPT algorithm always drives the operating point to the MPP and the center of voltage swing is always the voltage at MPP, reducing the dc-link voltage ripple in each cell can increase the average output power and the MPPT efficiency.

The dc-link voltage (or current) ripple reduction methods have been proposed for some systems and applications; for example, [21] proposed a dc-link ripple current reduction for paralleled three-phase voltage-source converter (VSC) with interleaving (this method requires two VSCs connected in paralleled), [22] proposed a dc-link voltage ripple reduction for a transformerless modular wind generator system, and [23] proposed a dc-link voltage ripple minimization method for a modular VSC for HVDC power transmission. This paper presents a dc-link voltage ripple reduction in each cell of the three-phase cascaded H-bridge multilevel PV system by injecting the third-harmonic zero-sequence voltage to improve the MPPT efficiency. The objective of the thirdharmonic zero-sequence voltage injection in this paper is different from that in [24] where it is used to increase the dclink utilization and obtain higher number of voltage levels. The method proposed in this paper does not introduce any additional circuit component. In addition, this paper also describes a control method to achieve individual MPPT control in each converter cell. The validity and effectiveness of the methods presented in this paper are verified by computer simulation.

\section{Circuit Configuration of the PV System}

According to Figure 1, each phase of the system is a series connection of multiple converter cells. Each converter cell consists of an $\mathrm{H}$-bridge inverter and a PV panel as an isolated dc source. The dc-link capacitor is installed in parallel with each PV panel as a power decoupling element for absorbing the PWM switching current produced at the dc side of each

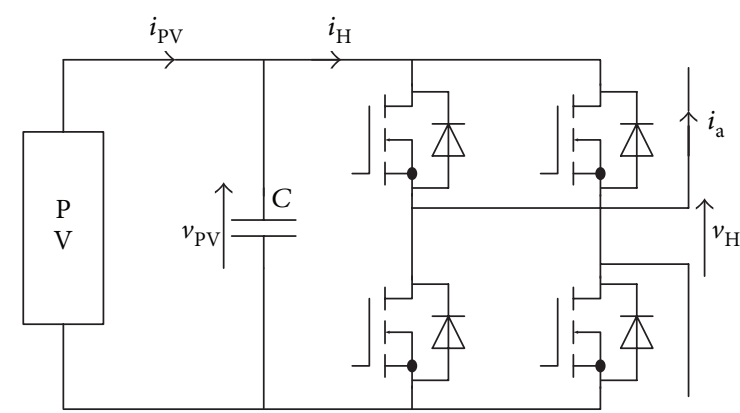

FIgure 3: Circuit diagram of cell a1.

$\mathrm{H}$-bridge inverter. The system is connected to the grid via aclink inductor(s) $L$. Each H-bridge inverter is modulated with a unipolar PWM technique and produces three-level PWM voltage. The frequency of triangular carrier signal for each cell is $f_{c}$. When several cells are connected in series, a phase-shift PWM (PS-PWM) modulation strategy is used to generate multilevel PWM voltage waveform. In this case, the number of output voltage levels becomes $2 n+1$ levels (line-to-neutral), where $n$ is the number of cells per phase. The phase shift of carrier signals of the adjacent cells is $\pi / n$ [25]. Due to the multiplicative effect of switching frequency of the PS-PWM, the system then achieves an output switching frequency of $2 n f_{c}$, while the device switching frequency is only at $f_{c}$. This has a positive effect on the system efficiency. Moreover, both the multilevel PWM and high switching frequency characteristics have a positive effect on the harmonic performance of the system.

\section{Principle of dc-Link Voltage Ripple Reduction}

This paper proposes the dc-link voltage ripple reduction by injecting the third-harmonic zero-sequence voltage component which can reduce the dc-link voltage ripple without introducing any additional circuit component. Since the third-harmonic zero-sequence voltage injection technique can be used only for three-phase three-wire systems, this paper focuses on the three-phase cascaded H-bridge PV system as shown in Figure 1(b) only.

Considering cell al depicted in Figure 3 in steady-state condition, the instantaneous power of capacitor $p_{C}$ has only ac component. Hence, by neglecting power losses of the $\mathrm{H}$-bridge inverter, the instantaneous power balance can be expressed as

$$
p_{\mathrm{C}}=\left(p_{\mathrm{PV}}\right)_{\mathrm{ac}}-\left(p_{\mathrm{H}}\right)_{\mathrm{ac}}=\left(v_{\mathrm{PV}} i_{\mathrm{PV}}\right)_{\mathrm{ac}}-\left(v_{\mathrm{H}} i_{\mathrm{a}}\right)_{\mathrm{ac}},
$$

where $p_{\mathrm{PV}}$ is the power flowing from the PV panel, $p_{\mathrm{H}}$ is the power flowing to the dc side of $\mathrm{H}$-bridge inverter, and $(y)_{\mathrm{ac}}$ is the ac component of $y$. In this case, $\left(v_{\mathrm{H}} i_{\mathrm{a}}\right)_{\mathrm{ac}}$ is much larger than $\left(v_{\mathrm{PV}} i_{\mathrm{PV}}\right)_{\mathrm{ac}}$ because $v_{\mathrm{H}}$ and $i_{\mathrm{a}}$ are both ac quantities while $v_{\mathrm{PV}}$ and $i_{\mathrm{PV}}$ are both dc quantities. Hence, the instantaneous power of capacitor $p_{C}$ at the steady-state can be approximated as

$$
p_{\mathrm{C}} \approx-\left(v_{\mathrm{H}} i_{\mathrm{a}}\right)_{\mathrm{ac}} \text {. }
$$


An approximated expression of the ac ripple component $\widetilde{v}_{C}$ of capacitor voltage can be calculated from the dc-link capacitor power $p_{C}$ as (see Appendix)

$$
\widetilde{v}_{C}=\frac{\int p_{C} d t}{C V_{C}}
$$

Hence, from (2) and (3), the ac ripple component of dc-link voltage can be expressed as

$$
\widetilde{v}_{\mathrm{PV}}=\frac{-\int\left(v_{\mathrm{H}} i_{\mathrm{a}}\right)_{\mathrm{ac}} d t}{C V_{\mathrm{PV}}}
$$

where $C$ is the capacitance of the dc-link capacitor and $V_{C}$ is the nominal capacitor voltage. It should be noted that $V_{\mathrm{PV}}$ and $V_{C}$ are equal.

Voltage $v_{\mathrm{H}}$ without the third-harmonic zero-sequence voltage injection is expressed as

$$
v_{\mathrm{H}}=V_{\mathrm{H}} \sin \omega t,
$$

while $v_{\mathrm{H}}$ with the third-harmonic zero-sequence voltage injection is expressed as

$$
v_{\mathrm{H}}=V_{\mathrm{H}}\left(\sin \omega t+A_{3} \sin 3 \omega t\right),
$$

where $A_{3}$ is the relative amplitude of the third-harmonic voltage. By assuming that the system operates with power factor close to unity, the grid current $i_{\mathrm{a}}$ is expressed as

$$
i_{\mathrm{a}}=I_{\mathrm{a}} \sin \omega t .
$$

Substituting (5), (6), and (7) into (4), the dc-link voltage ripple component without the third-harmonic zero-sequence voltage injection is expressed as

$$
\widetilde{v}_{\mathrm{PV}_{\text {org }}}=\frac{V_{\mathrm{H}} I_{\mathrm{a}}}{4 \omega C V_{\mathrm{PV}}} \sin 2 \omega t,
$$

while the dc-link voltage ripple with the third-harmonic zerosequence voltage injection is expressed as

$$
\widetilde{v}_{\mathrm{PV}_{\mathrm{inj}}}=\frac{V_{\mathrm{H}} I_{\mathrm{a}}}{4 \omega C V_{\mathrm{PV}}}\left(1-A_{3}\right) \sin 2 \omega t+\frac{V_{\mathrm{H}} A_{3} I_{\mathrm{a}}}{8 \omega C V_{\mathrm{PV}}} \sin 4 \omega t .
$$

Figure 4 shows the plots of the estimated waveforms of dclink voltage ripple $\widetilde{v}_{\mathrm{PV}}$ org and that of the dc-link voltage ripple with the third-harmonic zero-sequence voltage injection $\widetilde{v}_{\mathrm{PV}_{\text {ini }}}$ when $A_{3}=0.4$. It can be seen that injecting the thirdharmonic zero-sequence voltage can reduce the amplitude of the dc-link voltage ripple. Figure 5 shows the percentage of the dc-link voltage ripple reduction versus $A_{3}$ obtained from the theoretical calculation using (8) and (9), for $A_{3}=$ 0 to 0.8 . It shows that as $A_{3}$ increases more ripple amplitude reduction can be achieved. However, Figure 6 shows that the amplitude of $v_{\mathrm{H}}$ is higher than $100 \%$ when $A_{3}$ is larger than 0.4 (amplitude is equal to $100 \%$ when $A_{3}=0$ ). Hence, the relative amplitude $A_{3}$ cannot be increased arbitrarily without bound in order to prevent the overmodulation of $\mathrm{H}$-bridge inverter. The maximum possible value of $A_{3}$ depends on

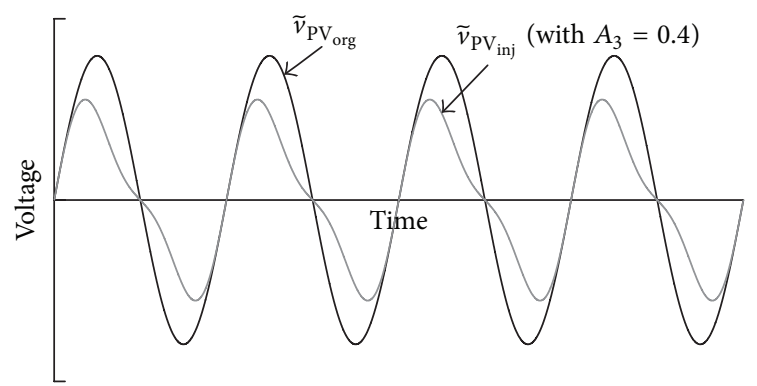

FIGURE 4: Estimation of dc-link voltage ripple without and with the third-harmonic zero-sequence voltage injection.

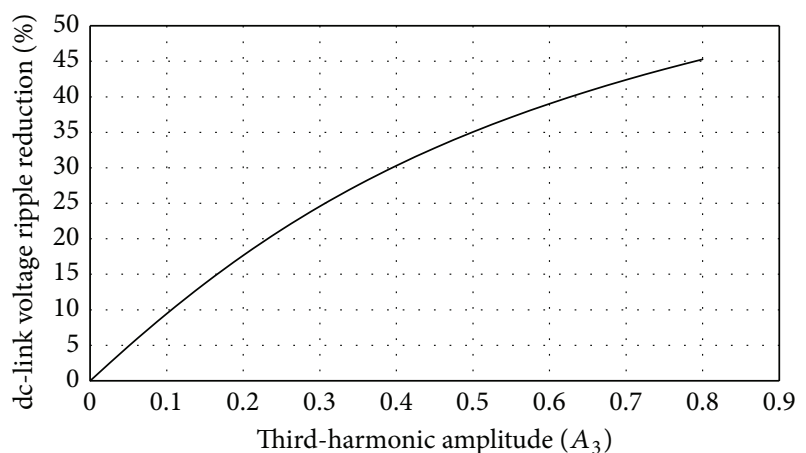

FIgUre 5: Amplitude reduction of dc-link voltage ripple versus $A_{3}$ when injecting third-harmonic zero-sequence voltage.

the modulation index of the $\mathrm{H}$-bridge inverter which is a ratio between the voltage amplitude $V_{\mathrm{H}}$ and the PV panel voltage at maximum power point $V_{\mathrm{mpp}}$. For example, when the modulation index is equal to 0.85 , the amplitude of $v_{\mathrm{H}}$ can be increased by the third-harmonic zero-sequence voltage injection up to $117 \%(=1 / 0.85 \times 100)$ before overmodulation occurs. Thus, the maximum possible value of $A_{3}$ is 0.6 according to Figure 6 . Hence, the dc-link voltage ripple amplitude reduction can be achieved up to $39 \%$ according to Figure 5.

\section{Method for Individual MPPT Control}

The principle of individual MPPT control is based on the individual control of the dc-link voltage of each converter cell. By considering Figure 3, the following relation can be obtained:

$$
i_{\mathrm{H}}=i_{\mathrm{PV}}-C \frac{d v_{\mathrm{PV}}}{d t} .
$$

Hence, the dc-link voltage $v_{\mathrm{PV}}$ can be controlled by controlling $i_{\mathrm{H}}$ using the proportional-integral (PI) controller as shown in Figure 7 , considering $i_{\mathrm{PV}}$ as a disturbance. In this case, $i_{\mathrm{H}}$ is related to $i_{\mathrm{a}}$ as

$$
i_{\mathrm{H}}=d \cdot i_{\mathrm{a}},
$$

where $d$ is the duty cycle of the H-bridge inverter. This means that the $\mathrm{H}$-bridge inverter works as a current-source 


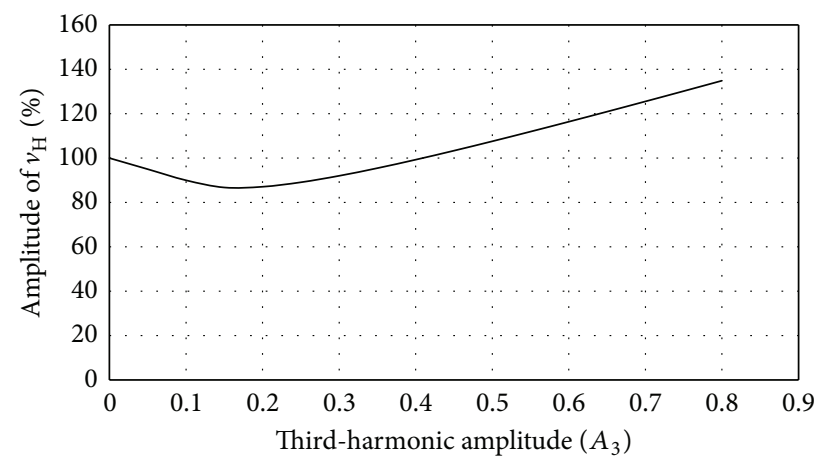

FIgURE 6: Amplitude of $v_{\mathrm{H}}$ versus $A_{3}$ with the third-harmonic zerosequence voltage injection $\left(100 \%\right.$ when $\left.A_{3}=0\right)$.

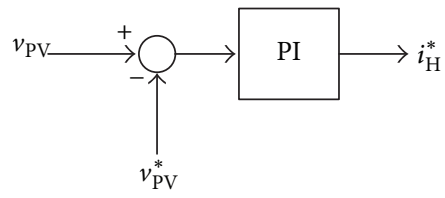

FIGURE 7: dc-link voltage controller (output is $i_{\mathrm{H}}^{*}$ ).

converter when seen from the dc side, where $i_{\mathrm{H}}$ can be made proportional to $i_{\mathrm{a}}$ by adjusting the duty cycle. Note that $d$ is an ac signal because $i_{\mathrm{a}}$ is an ac signal while $i_{\mathrm{H}}$ is a dc signal. Therefore, the product of $d$ and $i_{\mathrm{a}}$ becomes a dc signal. Assuming that $i_{\mathrm{a}}$ has a constant amplitude, the output of PI controller in Figure 7 is changed to $D$ in Figure 8, where $D$ is rms value of $d$. This means that the dc-link voltage can be controlled by adjusting the duty cycle of the $\mathrm{H}$-bridge inverter. However, adjusting duty cycle will also affect the $\mathrm{H}$ bridge inverter output voltage $v_{\mathrm{H}}$ because

$$
v_{\mathrm{H}}=d \cdot v_{\mathrm{PV}} \text {. }
$$

Thus, the duty cycle of each inverter in phase $x$ (where $x=\mathrm{a}, \mathrm{b}, \mathrm{c}$ ) cannot be adjusted arbitrarily; otherwise the summation of $v_{\mathrm{H}}$ in phase $x$ may not be equal to $v_{x}^{*}$, where $v_{x}^{*}$ is the voltage command for phase $x$ obtained from the grid current control. In order to simultaneously control the grid current and the individual dc-link voltage, the output voltage command of each inverter must be a weighted proportion of $v_{x}^{*}$ calculated by

$$
v_{\mathrm{H}}^{x j *}=v_{x}^{*} \frac{D_{x j} v_{\mathrm{PV}}^{x j}}{\sum_{j=1}^{n}\left(D_{x j} v_{\mathrm{PV}}^{x j}\right)},
$$

where $j=1-n$ and $D_{x j}$ is the rms value of the duty cycle of cell $x j$ obtained from the PI controller as shown in Figure 8.

The calculation of the voltage command $v_{x}^{*}$ for each phase is based on the grid current control using the conventional voltage-oriented control with $d q$-current decoupling [26]. The $d$-axis current command $i_{d}^{*}$ is calculated from the summation of error signals of all cells passing through the PI controller as shown in Figure 9, while the $q$-axis current command $i_{q}^{*}$ is set to zero.

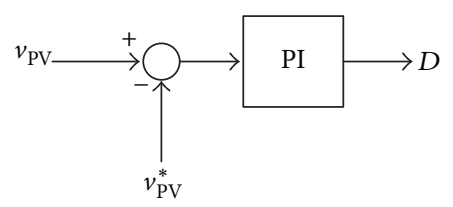

FIGURE 8: dc-link voltage controller (output is $D$ ).

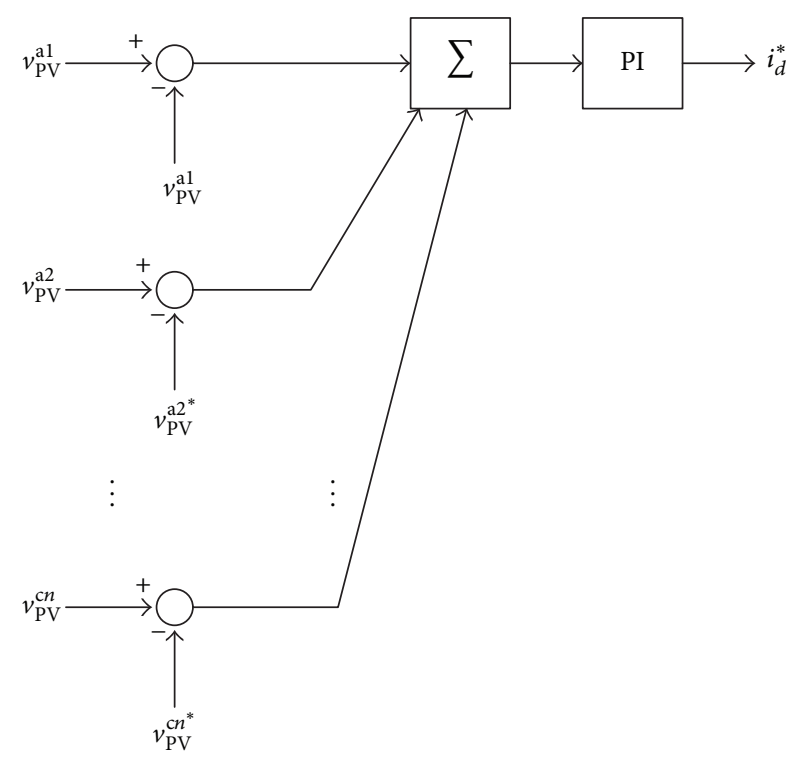

FIGURE 9: Calculation of $i_{d}^{*}$.

The calculation of the dc-link voltage command for each cell $v_{\mathrm{PV}}^{x j *}$ to achieve MPPT can be done by the conventional Perturb and Observe ( $\mathrm{P} \& \mathrm{O}$ ) method, the PI-based Incremental Conductance method, or others as described in [27].

\section{Simulation Results}

The simulation model of the three-phase cascaded H-bridge PV system in Figure 1(b) was created with four cells per phase. In this model, it is assumed that each H-bridge inverter is connected to a PV panel and a dc-link capacitor at the dclink network. The parameters of the PV panel are based on the PV panel model CHSM6610P-250 from Astronergy with the nominal output power of $250 \mathrm{~W}$. Table 1 summarizes the parameters used in the simulation model.

5.1. Simulation Results without the Third-Harmonic ZeroSequence Voltage Injection. Figure 10 shows the steady-state simulation results of the system in Figure 1(b) without the third-harmonic zero-sequence voltage injection. Figure 10 shows that the waveforms of the three-phase voltage command $\left(v_{\mathrm{a}}^{*}\right.$ and $\left.v_{\mathrm{b}}^{*}\right)$ are sinusoidal with only fundamental component. The waveforms of the line-to-line output voltages $\left(v_{\mathrm{ab}}\right.$ and $\left.v_{\mathrm{bc}}\right)$ are multilevel PWM voltage waveforms with 17 voltage levels. Therefore, the waveforms of the grid currents $\left(i_{\mathrm{a}}\right.$ and $\left.i_{\mathrm{b}}\right)$ are close to sinusoidal with small ripples and low THD. The peak amplitude of the grid current in this case is 

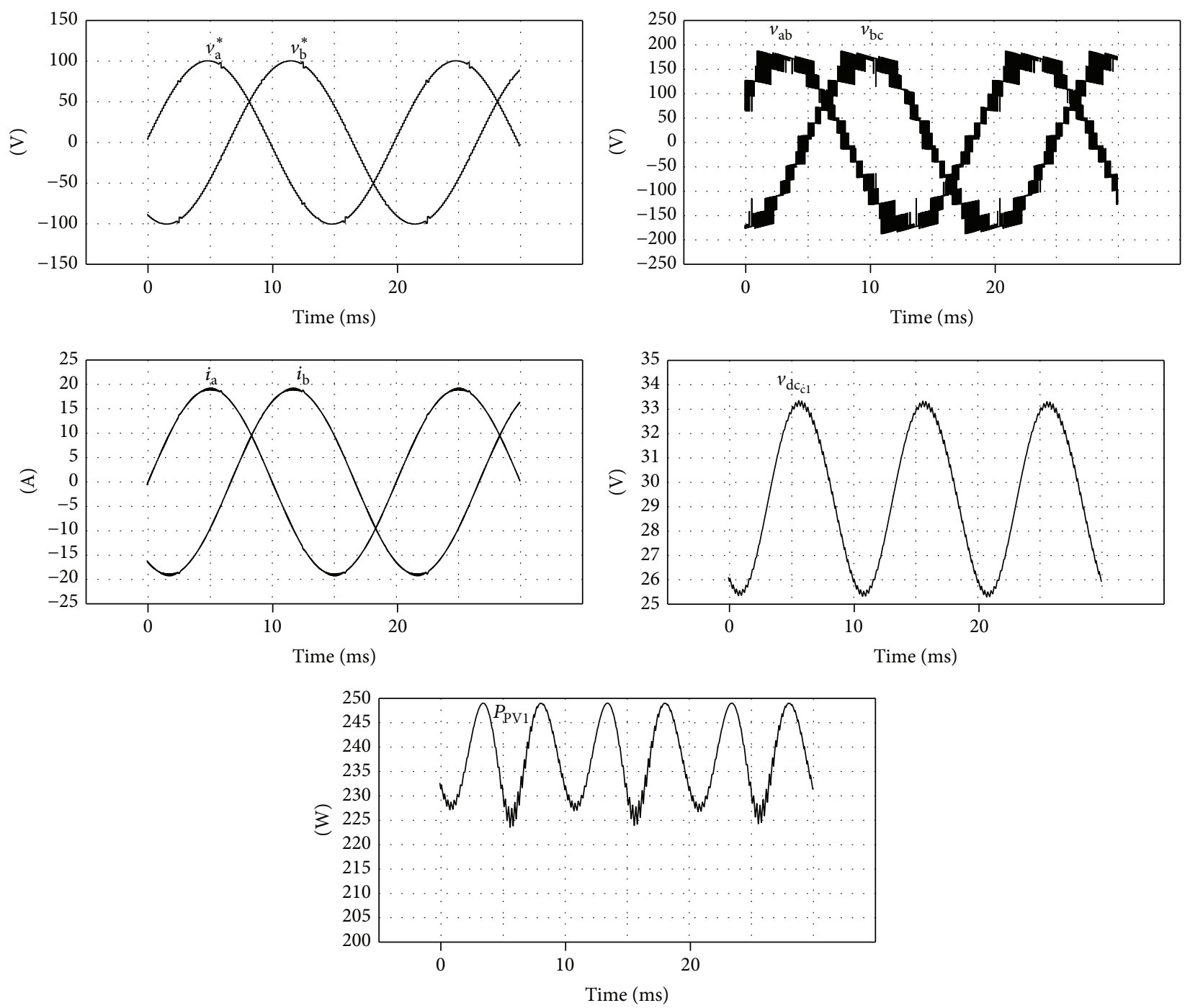

FIGURE 10: Simulation results without the third-harmonic zero-sequence voltage injection.

TABle 1: Parameters used in the simulation model.

\begin{tabular}{lc}
\hline PV panel open circuit voltage & $38 \mathrm{~V}$ \\
PV panel short circuit current & $9.1 \mathrm{~A}$ \\
PV panel maximum power voltage & $30 \mathrm{~V}$ \\
PV panel maximum power current & $8.3 \mathrm{~A}$ \\
PV panel nominal output power & $250 \mathrm{~W}$ \\
Number of cells per phase & 4 \\
DC capacitor & $3,300 \mu \mathrm{F}$ \\
AC inductor & $1 \mathrm{mH}$ \\
Grid voltage & $122.5 \mathrm{~V}-\mathrm{L}$ \\
Grid frequency & $50 \mathrm{~Hz}$ \\
System power rating & $3 \mathrm{~kW}$ \\
PWM carrier frequency & $2 \mathrm{kHz}$ \\
Output switching frequency & $16 \mathrm{kHz}$ \\
\hline
\end{tabular}

19.2 A. The dc-link voltage waveform of cell $\mathrm{cl} v_{\mathrm{dc}_{\mathrm{cl}}}$ contains a $100 \mathrm{~Hz}$ ripple of $8.2 \mathrm{~V}_{\mathrm{p}-\mathrm{p}}$ and a small switching-frequency ripple. The output power of $\mathrm{PV}$ panel of cell $\mathrm{cl} P_{\mathrm{PV} 1}$ contains a $200 \mathrm{~Hz}$ ripple of $25.7 \mathrm{~W}_{\mathrm{p} \text {-p }}$ and a small switching-frequency ripple with an average output power and peak output power of $238 \mathrm{~W}$ and $249 \mathrm{~W}$, respectively. The peak output power is the power at MPP which is equal to a product of maximum power voltage and maximum power current in Table $1(30 \mathrm{~V} \times$ 8.3 A). The total power produced by this system is calculated as

$$
p_{\text {total }}=v_{\mathrm{sa}} i_{\mathrm{a}}+v_{\mathrm{sb}} i_{\mathrm{b}}+v_{\mathrm{sc}} i_{\mathrm{c}}
$$

where $v_{\mathrm{sa}}, v_{\mathrm{sb}}$, and $v_{\mathrm{sc}}$ are the line-to-neutral grid voltages. In this case, the calculated total power is $2,856 \mathrm{~W}$. Note that the converter power loss is neglected in this simulation.

5.2. Simulation Results with the Third-Harmonic ZeroSequence Voltage Injection. Figure 11 shows the steady-state simulation results of the system in Figure 1(b) with the thirdharmonic zero-sequence voltage injection $\left(A_{3}=0.4\right)$. The waveforms of three-phase voltage command $\left(v_{\mathrm{a}}^{*}\right.$ and $\left.v_{\mathrm{b}}^{*}\right)$ are 

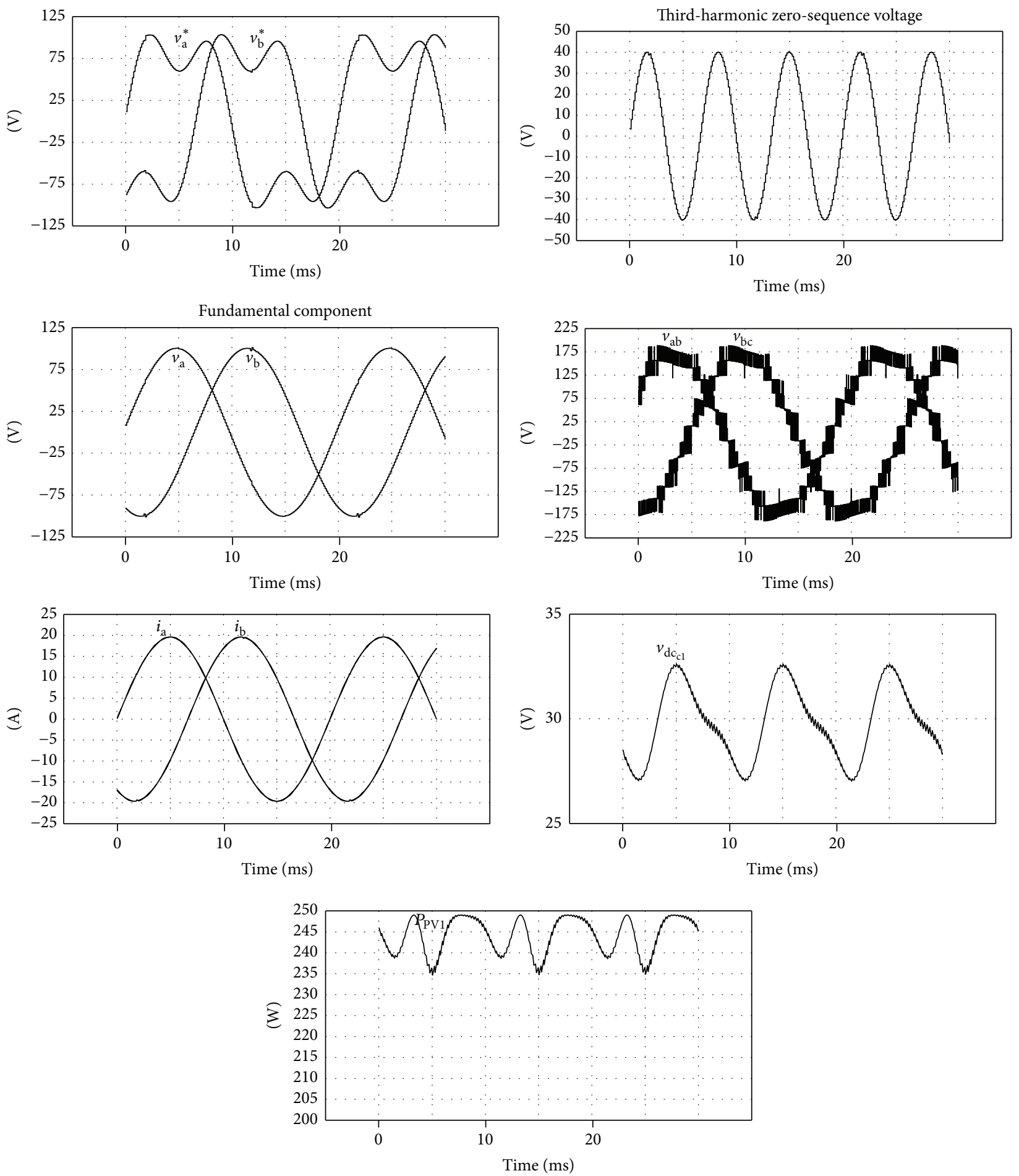

FIGURE 11: Simulation results with the third-harmonic zero-sequence voltage injection $\left(A_{3}=0.4\right)$.

the combinations of the fundamental component and the third-harmonic components. The waveforms of the line-toline output voltages $\left(v_{\mathrm{ab}}\right.$ and $\left.v_{\mathrm{bc}}\right)$ are multilevel PWM voltage waveforms similar to those in Figure 10. These waveforms do not contain the third-harmonic component because the system is the three-phase three-wire system which cancels the zero-sequence third-harmonic components out at the output. As a result, the waveforms of the grid currents $\left(i_{\mathrm{a}}\right.$ and $i_{\mathrm{b}}$ ) are still close to sinusoidal with only fundamental component. The peak amplitude of the grid current in this case is increased to $19.7 \mathrm{~A}$. The waveform of the dc-link voltage of cell $\mathrm{cl} v_{\mathrm{dc}}$ contains $100 \mathrm{~Hz}$ and $200 \mathrm{~Hz}$ ripple components as predicted by (9). The amplitude of the dc-link voltage ripple is decreased to $5.6 \mathrm{~V}_{\mathrm{p}-\mathrm{p}}$. It can be seen that the 
TABLE 2: Comparison of the results.

\begin{tabular}{lccc}
\hline & $\begin{array}{c}\text { w/o third-harmonic } \\
\text { injection }\end{array}$ & $\begin{array}{c}\text { w/third-harmonic } \\
\text { injection }\end{array}$ & $\begin{array}{c}\% \text { of } \\
\text { change }\end{array}$ \\
\hline $\begin{array}{l}\text { Grid current } \\
\text { peak amplitude } \\
\text { dc-link voltage } \\
\text { ripple amplitude }\end{array}$ & $19.2 \mathrm{~A}$ & $19.7 \mathrm{~A}$ & $+2.6 \%$ \\
$\begin{array}{l}\text { PV panel power } \\
\text { ripple amplitude }\end{array}$ & $25.7 \mathrm{~V}_{\mathrm{p}-\mathrm{p}-\mathrm{p}}$ & $5.6 \mathrm{~V}_{\mathrm{p}-\mathrm{p}}$ & $-32 \%$ \\
$\begin{array}{l}\text { PV panel power } \\
\text { at MPP }\end{array}$ & $249 \mathrm{~W}$ & $13.6 \mathrm{~W}_{\mathrm{p}-\mathrm{p}}$ & $-47 \%$ \\
$\begin{array}{l}\text { PV panel average } \\
\text { output power }\end{array}$ & $238 \mathrm{~W}$ & $249 \mathrm{~W}$ & \\
$\begin{array}{l}\text { Output power of } \\
\text { the system }\end{array}$ & $2,856 \mathrm{~W}$ & $244.3 \mathrm{~W}$ & $+2.6 \%$ \\
\hline
\end{tabular}

dc-link voltage waveform in Figure 11 and that in Figure 4 are similar. This confirms the validity of dc-link voltage ripple estimation presented in Section 3.

In Figure 11, the ripple output power waveform of PV panel of cell $\mathrm{cl}$ is a multifrequency waveform. The amplitude of the power ripple is decreased to $13.6 \mathrm{~W}_{\mathrm{p} \text {-p }}$ with an average output power increased to $244.3 \mathrm{~W}$. The peak power waveform remains $249 \mathrm{~W}$. In this case, the total power produced by this system is $2,932 \mathrm{~W}$ (calculated by (14)) which is increased about $2.6 \%$ from the previous case.

5.3. Comparison of the Results. Table 2 shows the comparison of the simulation results of the two cases. It can be seen that injecting the third-harmonic zero-sequence voltages with $A_{3}=0.4$ can reduce the amplitudes of the dc-link voltage ripple by $32 \%$. The PV panel power ripple is also decreased, while the peak of power ripple remains unchanged (equal to the power at MPP). As a result, the average output power of each PV panel is increased and the total output power is also increased for the same amount. According to the simulation results, the total output power is increased about $2.6 \%$ without any additional circuit component. However, it should be noted that the percentage of the increased power also depends on the accuracy of the current-voltage characteristics of the PV panel used in the simulation.

It should also be noted that the value of the dc-link voltage ripple reduction of $32 \%$ in Table 2 is consistent with the value of about $30 \%$ in Figure 5. This means that the theoretical estimation of the dc-link voltage ripple presented in Section 3 is accurate.

\section{Conclusion}

This paper presents a dc-link voltage ripple reduction of the three-phase cascaded $\mathrm{H}$-bridge multilevel PV system using the third-harmonic zero-sequence voltage injection. Therefore, this method is valid only for three-phase threewire systems. The injection of third-harmonic zero-sequence voltage can reduce the amplitudes of the voltage ripple and power ripple of each PV panel. As a result, the average output power of each PV panel and the total output power are increased. According to the simulation results, the dc-link voltage ripple reduction is $32 \%$ when the relative amplitude of the third-harmonic voltage is 0.4 , resulting in the total power increase of $2.6 \%$ without any additional circuit component. This paper also presents a control method to achieve an individual MPPT control of each converter cell.

\section{Appendix}

\section{Derivation of dc-Link Voltage Ripple Equation}

The derivation presented in this section is the same as [28] and is repeated here for completeness. The dc-link voltage $v_{\mathrm{PV}}(t)$ of each cell is equal to the dc-link capacitor voltage $v_{C}(t)$. Denote the dc-link capacitor instantaneous power by $p_{C}(t)$ and the dc-link capacitor instantaneous energy by $W_{C}(t) \cdot v_{C}(t), p_{C}(t)$, and $W_{C}(t)$ can be related as

$$
W_{C}(t)=\int p_{C}(t) d t=\frac{1}{2} C\left(v_{C}(t)\right)^{2}=W_{0}+\widetilde{W}_{C}(t)
$$

Equation (A.1) shows that $W_{C}(t)$ can be expressed as a summation of the dc component $W_{0}$ and the ac component $\widetilde{W}_{C}(t)$. From (A.1), the dc-link capacitor voltage $v_{C}(t)$ can be expressed as

$$
v_{C}(t)=\sqrt{\frac{2}{C} W_{C}(t)}=V_{C}+\widetilde{v}_{C}(t) .
$$

Equation (A.2) shows that $v_{C}(t)$ can be expressed as a summation of dc mean voltage $V_{C}$ and the ac ripple component $\widetilde{v}_{C}(t)$. The objective of the following section is to find $\widetilde{v}_{C}(t)$.

Define $v_{C}(t)=f(x)$ and $x=(2 / C) W_{C}(t)$. Hence, from (A.2), the following equations are obtained:

$$
\begin{aligned}
f(x) & =\sqrt{x} \\
f^{\prime}(x) & =\frac{1}{2 \sqrt{x}} .
\end{aligned}
$$

Next, choose a point $t=a$ for Taylor series expansion of $f(x)$ which makes $W_{C}(a)=W_{0}\left(\widetilde{W}_{C}(a)=0\right)$. Then, the following equations are obtained:

$$
\begin{aligned}
\left.x\right|_{t=a} & =x_{0}=\frac{2 W_{0}}{C}, \\
f\left(x_{0}\right) & =\sqrt{\frac{2 W_{0}}{C}}, \\
f^{\prime}\left(x_{0}\right) & =\frac{1}{2 \sqrt{2 W_{0} / C}} .
\end{aligned}
$$

The function $f(x)$ can be approximated by Taylor series expansion around the point $x_{0}$ as

$$
f(x) \approx f\left(x_{0}\right)+f^{\prime}\left(x_{0}\right)\left(x-x_{0}\right)
$$


By substituting (A.4) into (A.5), the following equation is obtained:

$$
\begin{aligned}
f(x) & =\sqrt{\frac{2 W_{0}}{C}}+\frac{(2 / C) W_{C}(t)-2 W_{0} / C}{2 \sqrt{2 W_{0} / C}} \\
& =\sqrt{\frac{2 W_{0}}{C}}+\frac{\widetilde{W}_{C}(t)}{\sqrt{2 C W_{0}}} .
\end{aligned}
$$

By comparing (A.6) with (A.2), the terms $V_{C}$ and $\widetilde{v}_{C}(t)$ can be expressed as

$$
\begin{aligned}
V_{C} & =\sqrt{\frac{2 W_{0}}{C}}, \\
\widetilde{v}_{C}(t) & =\frac{\widetilde{W}_{C}(t)}{\sqrt{2 C W_{0}}}=\frac{\widetilde{W}_{C}(t)}{C V_{C}}=\frac{\int_{0}^{t}\left(p_{C}(\tau)\right)_{\mathrm{ac}} d \tau}{C V_{C}} .
\end{aligned}
$$

Therefore, the ac ripple component $\widetilde{v}_{C}(t)$ can be calculated

\begin{tabular}{|c|c|}
\hline$(y)_{\mathrm{ac}}:$ & ac component of $y$ \\
\hline$A_{3}:$ & Relative amplitude of third-harmonic voltage \\
\hline$C:$ & Capacitance of dc-link capacitor \\
\hline$d:$ & Duty cycle signal of bridge cell \\
\hline$D:$ & rms value of $d$ \\
\hline$D_{x j}:$ & rms duty cycle of $j$ th cell of phase $x$ \\
\hline$i_{\mathrm{a}}:$ & Grid current of phase a \\
\hline$I_{\mathrm{a}}:$ & Amplitude of $i_{\mathrm{a}}$ \\
\hline$i_{d}^{*}:$ & $d$-axis current reference of the system \\
\hline$i_{q}^{*}:$ & $q$-axis current reference of the system \\
\hline$i_{\mathrm{H}}:$ & Current of bridge cell at the dc side \\
\hline$i_{\mathrm{PV}}:$ & Current of PV panel \\
\hline$p_{C}:$ & Instantaneous power of dc-link capacitor \\
\hline$p_{\mathrm{H}}:$ & Instantaneous power of bridge cell at the ac side \\
\hline$p_{\mathrm{PV}}:$ & Instantaneous power of PV panel \\
\hline$v_{C}:$ & dc-link capacitor voltage \\
\hline$\widetilde{v}_{C}:$ & $\begin{array}{l}\text { ac ripple component of dc-link capacitor } \\
\text { voltage }\end{array}$ \\
\hline$V_{C}:$ & dc mean value of dc-link capacitor voltage \\
\hline$v_{\mathrm{H}}:$ & Output voltage of bridge cell at the ac side \\
\hline$V_{\mathrm{H}}:$ & Amplitude of $v_{\mathrm{H}}$ \\
\hline$v_{\mathrm{PV}}:$ & Voltage of PV panel \\
\hline$\widetilde{v}_{\mathrm{PV}}:$ & ac ripple component of PV panel voltage \\
\hline$V_{\mathrm{PV}}:$ & dc mean value of PV panel voltage \\
\hline$\widetilde{v}_{\mathrm{PV}_{\text {org }}}:$ & $\begin{array}{l}\text { Ripple component of PV panel voltage without } \\
\text { third-harmonic injection }\end{array}$ \\
\hline$\widetilde{v}_{\mathrm{PV}}$ inj & $\begin{array}{l}\text { Ripple component of PV panel voltage with } \\
\text { third-harmonic injection }\end{array}$ \\
\hline$v_{x}^{*}:$ & Voltage reference of phase $x$ \\
\hline$v_{\mathrm{H}}^{x j *}:$ & Reference of $v_{\mathrm{H}}$ for $j$ th cell of phase $x$ \\
\hline$v_{\mathrm{PV}}^{x j}:$ & PV panel voltage of $j$ th cell of phase $x$ \\
\hline$v_{\mathrm{sa}}, v_{\mathrm{sb}}, v_{\mathrm{sc}}:$ & Line-to-neutral grid voltages \\
\hline$W_{C}:$ & Instantaneous energy of dc-link capacitor \\
\hline$W_{0}:$ & dc component of $W_{C}$ \\
\hline$\widetilde{W}_{C}:$ & ac component of $W_{C}$ \\
\hline . & Fundamental angular frequency of the syst \\
\hline
\end{tabular}
from the ac component of the dc-link capacitor power $\left(p_{C}(t)\right)_{\mathrm{ac}}$.

\section{Nomenclature}

\section{Competing Interests}

The authors declare that they have no competing interests.

\section{References}

[1] SolarPower Europe, Global Market Outlook for Solar Power 2015-2019, SolarPower Europe, Brussel, Belgium, 2015.

[2] J. M. A. Myrzik and M. Calais, "String and module integrated inverters for single-phase grid connected photovoltaic systems-a review," in Proceedings of the IEEE Bologna PowerTech Conference, vol. 2, pp. 430-437, Bologna, Italy, June 2003.

[3] S. B. Kjaer, J. K. Pedersen, and F. Blaabjerg, "A review of singlephase grid-connected inverters for photovoltaic modules," IEEE Transactions on Industry Applications, vol. 41, no. 5, pp. 12921306, 2005.

[4] M. Calais, J. Myrzik, T. Spooner, and V. G. Agelidis, "Inverters for single-phase grid connected photovoltaic systemsan overview," in Proceedings of the IEEE 33rd Annual Power Electronics Specialists Conference (PESC '02), vol. 4, pp. 19952000, June 2002.

[5] Q. Li and P. Wolfs, "A review of the single phase photovoltaic module integrated converter topologies with three different DC link configurations," IEEE Transactions on Power Electronics, vol. 23, no. 3, pp. 1320-1333, 2008.

[6] N. Femia, G. Lisi, G. Petrone, G. Spagnuolo, and M. Vitelli, "Distributed maximum power point tracking of photovoltaic arrays: novel approach and system analysis," IEEE Transactions on Industrial Electronics, vol. 55, no. 7, pp. 2610-2621, 2008.

[7] A. Bidram, A. Davoudi, and R. S. Balog, "Control and circuit techniques to mitigate partial shading effects in photovoltaic arrays," IEEE Journal of Photovoltaics, vol. 2, no. 4, pp. 532-546, 2012.

[8] S. Alepuz, S. Busquets-Monge, J. Bordonau, J. Gago, D. González, and J. Balcells, "Interfacing renewable energy sources to the utility grid using a three-level inverter," IEEE Transactions on Industrial Electronics, vol. 53, no. 5, pp. 1504-1511, 2006.

[9] R. González, E. Gubía, J. López, and L. Marroyo, “Transformerless single-phase multilevel-based photovoltaic inverter," IEEE Transactions on Industrial Electronics, vol. 55, no. 7, pp. 26942702, 2008.

[10] E. Villanueva, P. Correa, J. Rodriguez, and M. Pacas, "Control of a single-phase cascaded $\mathrm{H}$-bridge multilevel inverter for grid-connected photovoltaic systems," IEEE Transactions on Industrial Electronics, vol. 56, no. 11, pp. 4399-4406, 2009.

[11] B. Xiao, L. Hang, J. Mei, C. Riley, L. M. Tolbert, and B. Ozpineci, "Modular cascaded H-bridge multilevel PV inverter with distributed MPPT for grid-connected applications," IEEE Transactions on Industry Applications, vol. 51, no. 2, pp. 17221731, 2015.

[12] Y. Yu, G. Konstantinou, B. Hredzak, and V. G. Agelidis, "Power balance optimization of cascaded H-bridge multilevel converters for large-scale photovoltaic integration," IEEE Transactions on Power Electronics, vol. 31, no. 2, pp. 1108-1120, 2016.

[13] Y. Yu, G. Konstantinou, B. Hredzak, and V. G. Agelidis, "Power balance of cascaded H-bridge multilevel converters for largescale photovoltaic integration," IEEE Transactions on Power Electronics, vol. 31, no. 1, pp. 292-303, 2016.

[14] Y. Yu, G. Konstantinou, B. Hredzak, and V. G. Agelidis, "Operation of cascaded H-bridge multilevel converters for largescale photovoltaic power plants under bridge failures," IEEE 
Transactions on Industrial Electronics, vol. 62, no. 11, pp. 72287236, 2015.

[15] C. D. Townsend, Y. Yu, G. Konstantinou, and V. G. Agelidis, "Cascaded H-bridge multilevel PV topology for alleviation of per-phase power imbalances and reduction of second harmonic voltage ripple," IEEE Transactions on Power Electronics, vol. 31, no. 8, pp. 5574-5586, 2016.

[16] J. Chavarría, D. Biel, F. Guinjoan, C. Meza, and J. J. Negroni, "Energy-balance control of PV cascaded multilevel gridconnected inverters under level-shifted and phase-shifted PWMs," IEEE Transactions on Industrial Electronics, vol. 60, no. 1, pp. 98-111, 2013.

[17] D. Sun, B. Ge, X. Yan et al., "Modeling, impedance design, and efficiency analysis of quasi-Z source module in cascaded multilevel photovoltaic power system," IEEE Transactions on Industrial Electronics, vol. 61, no. 11, pp. 6108-6117, 2014.

[18] M. Coppola, F. D. Napoli, P. Guerriero, D. Iannuzzi, S. Daliento, and A. D. Pizzo, "An FPGA-based advanced control strategy of a gridtied PV CHB inverter," IEEE Transactions on Power Electronics, vol. 31, no. 1, pp. 806-816, 2016.

[19] Y. Liu, B. Ge, H. Abu-Rub, and F. Z. Peng, "An effective control method for three-phase quasi-Z-source cascaded multilevel inverter based grid-tie photovoltaic power system," IEEE Transactions on Industrial Electronics, vol. 61, no. 12, pp. 6794-6802, 2014.

[20] C. Cecati, F. Ciancetta, and P. Siano, "A multilevel inverter for photovoltaic systems with fuzzy logic control," IEEE Transactions on Industrial Electronics, vol. 57, no. 12, pp. 4115-4125, 2010.

[21] D. Zhang, F. Wang, R. Burgos, R. Lai, and D. Boroyevich, "DC-link ripple current reduction for paralleled three-phase voltage-source converters with interleaving," IEEE Transactions on Power Electronics, vol. 26, no. 6, pp. 1741-1753, 2011.

[22] X. B. Yuan, Y. D. Li, J. Y. Chai, and J. Wang, "DC-link voltage ripple reduction for a transformerless modular wind generator system," in Proceedings of the 5th IET International Conference on Power Electronics, Machines and Drives (PEMD '10), pp. 1-6, Brighton, UK, April 2010.

[23] M. Tomasini, R. Feldman, J. C. Clare, P. Wheeler, D. R. Trainer, and R. S. Whitehouse, "DC-link voltage ripple minimization in a modular multilevel voltage source converter for HVDC power transmission," in Proceedings of the 14th European Conference on Power Electronics and Applications (EPE '11), pp. 1-10, Birmingham, UK, September 2011.

[24] S. K. Chattopadhyay, C. Chakraborty, and B. C. Pal, "A hybrid multilevel inverter topology with third harmonic injection for grid connected photovoltaic central inverters," in Proceedings of the 21st IEEE International Symposium on Industrial Electronics (ISIE '12), pp. 1736-1741, Hangzhou, China, May 2012.

[25] B. P. McGrath and D. G. Holmes, "Multicarrier PWM strategies for multilevel inverters," IEEE Transactions on Industrial Electronics, vol. 49, no. 4, pp. 858-867, 2002.

[26] L. Maharjan, S. Inoue, and H. Akagi, "A transformerless energy storage system based on a cascade multilevel PWM converter with star configuration," IEEE Transactions on Industry Applications, vol. 44, no. 5, pp. 1621-1630, 2008.

[27] T. Esram and P. L. Chapman, "Comparison of photovoltaic array maximum power point tracking techniques," IEEE Transactions on Energy Conversion, vol. 22, no. 2, pp. 439-449, 2007.

[28] H. Fujita, M. Hagiwara, and H. Akagi, "Power flow analysis and DC-capacitor voltage regulation for the MMCC-DSCC, IEEJ Transactions on Industry Applications, vol. 132, no. 6, pp. 659665, 2012 (Japanese). 

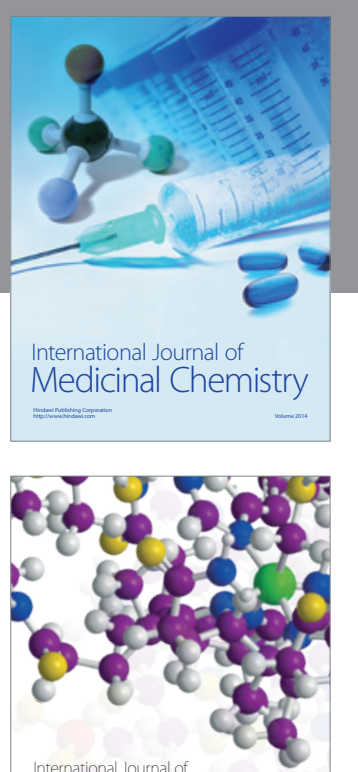

Carbohydrate Chemistry

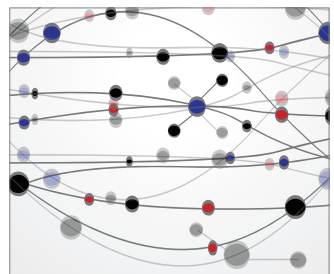

The Scientific World Journal
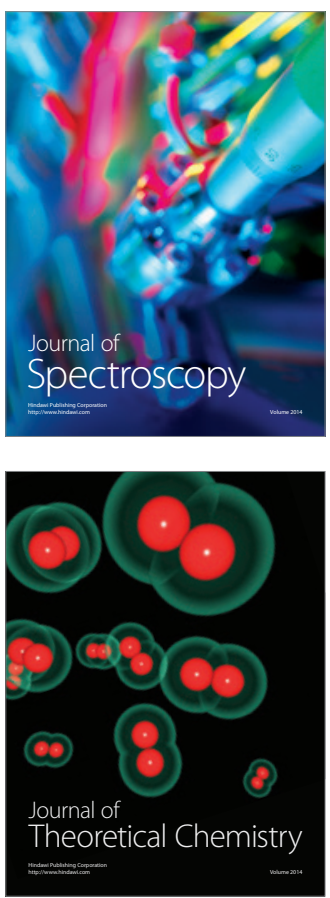
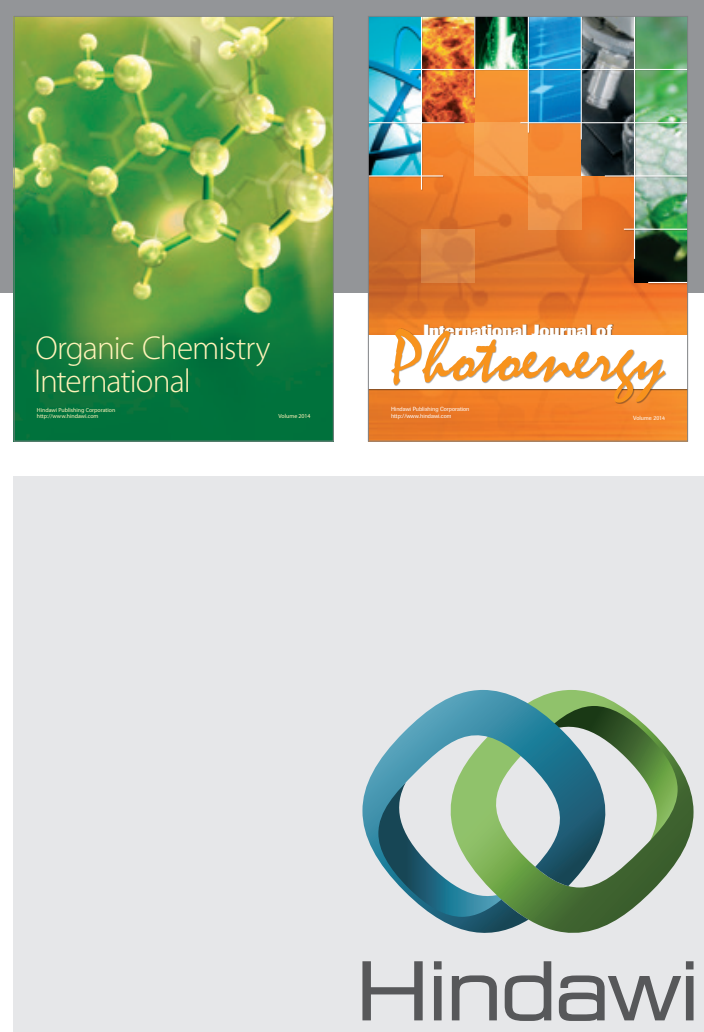

Submit your manuscripts at

http://www.hindawi.com

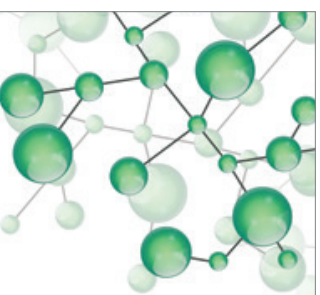

International Journal of

Inorganic Chemistry

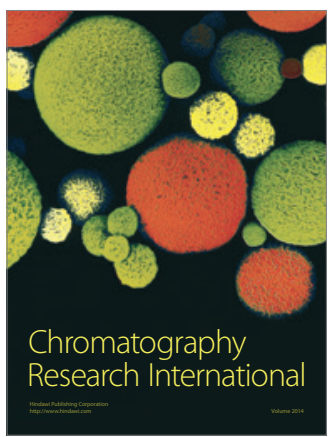

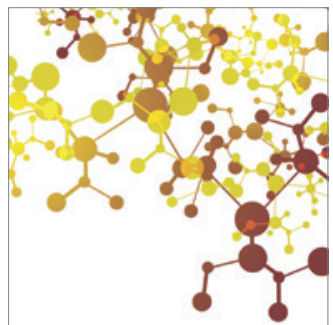

Applied Chemistry
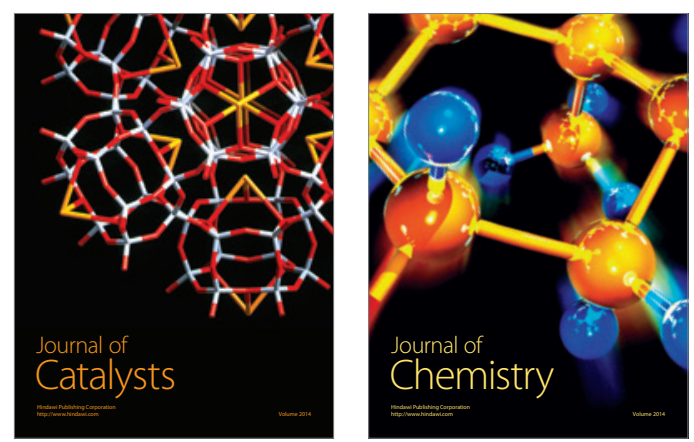
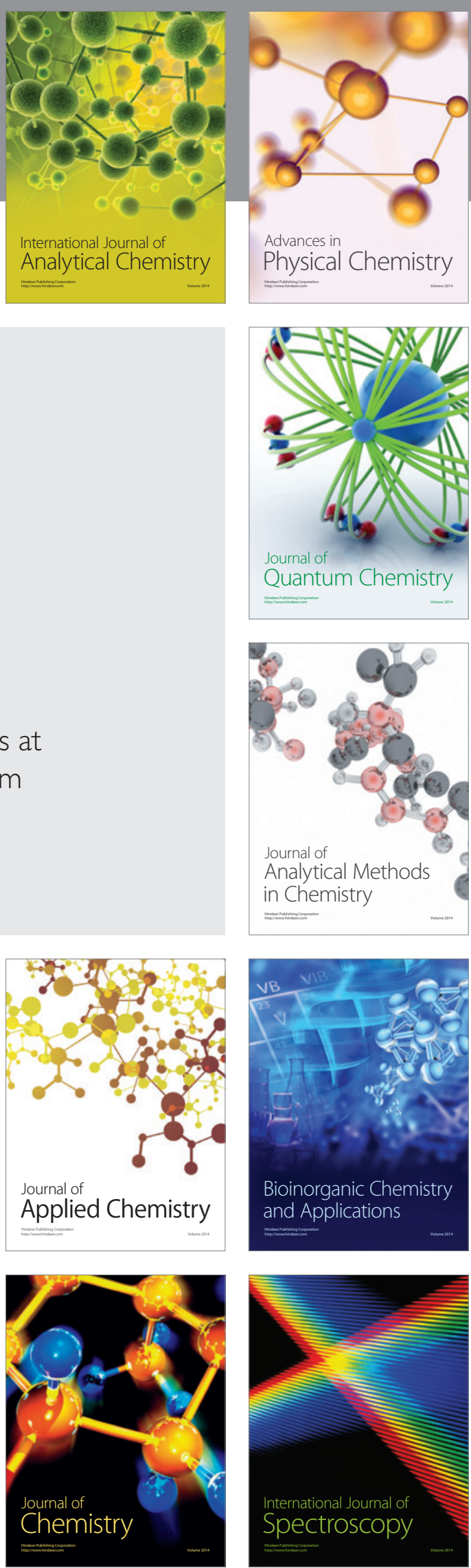